\title{
PENGARUH KEADILAN ORGANISASI DALAM PENILAIAN KINERJA TERHADAP KEPUASAN PENILAIAN DAN KINERJA KARYAWAN
}

\author{
Masrukin, Musa Hubeis \& Hari Wijayanto \\ Program Magister Bisnis, Sekolah Bisnis Institut Pertanian Bogor \\ E-mail: masrukin.stp@gmail.com
}

\begin{abstract}
ABSTRAK
Sejak 2012, manajemen PTPN $\vee$ Pekanbaru menerapkan sistem penilaian kinerja berbasis kompetensi (Competency-Based Performance Management atau CBPM). Perbedaan CBPM dari sistem sebelumnya adalah CBPM menggunakan indikator kinerja terukur, sedangkan dalam sistem lama penilaian kinerja dilakukan dengan metode graphic rating scale. Salah satu indikator efektivitas penilaian kinerja adalah keadilan organisasi dalam penilaian kinerja. Tujuan dari penelitian ini adalah menganalisis keadilan organisasi dalam penilaian kinerja dan pengaruhnya terhadap kepuasan penilaian dan kinerja karyawan. Data dikumpulkan dari 196 responden karyawan manajerial menggunakan kuesioner online dengan teknik purposive sampling. Analisis deskriptif dengan analisis nilai rata-rata dan analisis rentang kriteria. Pengujian hipotesis dilakukan dengan analisis Structural Equation Modeling-Partial Least Square (SEM-PLS). Hasil analisis deskriptif menunjukkan keadilan organisasi dalam penilaian kinerja telah berjalan dengan baik dan karyawan telah puas terhadap penilaian kinerja. Analisis SEM-PLS menunjukkan keadilan organisasional dalam penilaian kinerja berpengaruh terhadap kepuasan penilaian kinerja dan kinerja karyawan secara signifikan. Kepuasan penilaian kinerja tidak berperan memediasi pengaruh keadilan dalam penilaian kinerja terhadap kinerja karyawan.
\end{abstract}

Kata Kunci: Kinerja karyawan, keadilan organisasi, penilaian kinerja berbasis kompetensi, kepuasan penilaian kinerja

Klasifikasi JEL: M540

ABSTRACT
Since 2012, management of PTPN $\vee$ Pekanbaru implemented a new system of performance appraisal, named Competency-Based Performance Management (CBPM) for replaced the earlier system. The difference between CBPM and the earlier system is CBPM use a set of measured performance indicator, while in the old system, performance appraisal done by graphic rating scale method. One of performance appraisal effectiveness indicator is organizational justice on performance appraisal. The purpose of this study is to analyze organizational justice in performance appraisal and their influence on satisfaction toward performance appraisal and employee's performance. Data collected from 196 respondents from managerial employee by a set of online questionnaire with purposive sampling's technique. Descriptive analysis carried out by mean value's analysis and range's criteria analysis. Hypothesis testing has done by Structural Equation Modelling-Partial Least Square (SEM-PLS) analysis. The descriptive analysis shows that organizational justice in the performance appraisal had run well and the employees had satisfied toward the performance appraisal. SEM-PLS analysis shows that organizational justice in performance appraisal effect to satisfaction of performance appraisal and employee's performance significantly. Satisfaction toward performance appraisal does not play a role in mediating the influence of justice in the performance appraisal to employee performance

Keywords: employee's performance, organizational justice, competency-based performance appraisal, performance appraisal satisfaction

JEL Classification: M540 


\section{Masrukin}

\section{Musa Hubeis \\ Hari Wijayanto}

\section{PENDAHULUAN}

Penilaian kinerja merupakan salah satu hal penting dari aktifitas manajemen sumber daya manusia (MSDM) di setiap organisasi atau perusahaan. Penilaian kinerja adalah proses mengevaluasi kinerja karyawan terhadap suatu standar yang ditetapkan berdasarkan tujuan perusahaan (Mangkuprawira, 2011). Tujuan pelaksanaan penilaian kinerja ada tiga macam, yakni tujuan strategik, tujuan administratif dan tujuan pengembangan. Tujuan strategik adalah penilaian kinerja menghubungkan aktifitas-aktifitas karyawan dengan sasaran organisasi. Tujuan administratif adalah informasi-informasi penilaian kinerja menjadi bahan dalam pengambilan keputusan-keputusan administratif seperti aktifitas penggajian, promosi, menangani retensi, pemutusan hubungan kerja dan pengakuan atas kinerja individu. Tujuan pengembangan adalah penilaian kinerja memberikan informasi kelemahankelemahan yang dimiliki karyawan untuk dilakukan perbaikan melalui pelatihan-pelatihan (Noe et al., 2010).

Sistem penilaian kinerja yang didesain dan diimplementasikan dengan baik dapat memberikan manfaat bagi karyawan maupun perusahaan. Manfaat penilaian kinerja meliputi: perbaikan kinerja, penyesuaian kompensasi, keputusan penempatan, kebutuhan pelatihan dan pengembangan, perencanaan karir, informasi ketidakakuratan analisis jabatan, indikasi kesalahan rancangan pekerjaan, kesempatan penempatan kerja yang sama dan umpan balik kinerja departemen SDM (Mangkuprawira, 2011).

Manfaat penilaian kinerja diperoleh apabila sistem penilaian kinerja berjalan efektif. Efektfitas sistem penilaian kinerja ditentukan oleh persepsi keadilan yang dirasakan karyawan dan reaksi karyawan merupakan aspek penting penilaian kinerja. Kepuasan penilaian kinerja merupakan salah satu reaksi karyawan terhadap penilaian kinerja yang menentukan efektifitas sistem penilaian kinerja (Jawahar, 2007). Penilaian kinerja dapat menjadi alat praktis untuk motivasi dan pengembangan karyawan, jika karyawan merasa bahwa sistem tersebut akurat dan adil. Sebaliknya, proses penilaian dapat menjadi sumber ketidakpuasan yang ekstrim ketika karyawan percaya sistem ini bias, bernuansa politis, atau tidak relevan (Thurston \& McNall, 2010).

Perseroan Terbatas Perkebunan Nusantara (PTPN) $\vee$ adalah sebuah perusahaan perkebunan milik pemerintah yang saat ini tergabung dalam Holding Perkebunan Nusantara dengan PTPN III sebagai perusahaan induk (Champion). Sejak tahun 2012, Manajemen PTPN $\vee$ telah menerapkan sistem penilaian kinerja berbasis kompetensi (Competency-Based Performance Management atau CBPM) untuk menggantikan sistem penilaian lama yang 
masih bersifat subyektif. Berdasarkan hasil survei kepuasan karyawan yang dilakukan oleh manajemen PTPN V, selama periode 2013-2015 tingkat kepuasan karyawan relatif tetap, yakni pada tingkat kepuasan sedang. Hal ini mengindikasikan perubahan sistem penilaian kinerja belum dapat meningkatkan kepuasan karyawan atau dikatakan penilaian kinerja belum efektif. Penelitian ini bertujuan menganalisis pengaruh keadilan organisasi dalam penilaian kinerja terhadap kepuasan penilaian dan kinerja karyawan di PT. Perkebunan Nusantara (PTPN) V Pekanbaru Riau.

\section{TINJAUAN PUSTAKA}

\section{Keadilan Organisasi dalam Penilaian Kinerja}

Keadilan organisasi adalah persepsi keseluruhan keadilan yang dirasakan oleh karyawan (Robbins \& Judge, 2016). Keadilan organisasi merefleksikan penerimaan seseorang atas perlakuan yang adil dalam pekerjaan (Kreitner \& Kinicki, 2014). Keadilan organisasi dalam penilaian kinerja terdiri atas empat aspek, yaitu keadilan distributif, keadilan prosedural, keadilan interpersonal dan keadilan informasional (Robbins \& Judge, 2016; Thurston \& McNall, 2010).

Keadilan distributif adalah persepsi karyawan tentang keadilan alokasi hasil penilaian kinerja berupa nilai kinerja dan keputusan-keputusan administratif yang terkait nilai kinerja, seperti: gaji, promosi dan penghargaan lainnya (Palaiologos et al., 2011). Keadilan prosedural adalah persepsi karyawan tentang keadilan yang dirasakan dalam hal proses dan prosedur yang digunakan untuk membuat keputusan-keputusan pendistribusian (Wibowo, 2013; Kreitner \& Kinicki, 2014). Keadilan prosedural dalam penilaian kinerja meliputi prinsip-prinsip: konsistensi, peniadaan bias, keakuratan informasi, kemungkinan koreksi, keterwakilan dan kesantunan (Thurston \& McNall, 2010).

Keadilan interpersonal adalah mutu perlakuan interpersonal yang diterima karyawan selama berlakunya prosedur pendistribusian dalam perusahaan (Thurston \& McNall, 2010). Karyawan memiliki persepsi keadilan interpersonal jika diperlakukan secara hormat dan bermartabat (Wibowo, 2013). Keadilan informasional menekankan pada kesediaan para atasan untuk memberikan penjelasan atas keputusan-keputusan penting menyangkut bawahannya dan para atasan menyampaikan informasi secara jujur (Colquitt, 2001).

\section{Kepuasan Penilaian Kinerja}

Reaksi karyawan terhadap penilaian kinerja merupakan indikator penting bagi penerimaan karyawan terhadap sistem penilaian (Jawahar, 2007). Reaksi karyawan atas penilaian kinerja menentukan efektifitas sistem penilaian kinerja (Sudin, 2011). Salah satu reaksi penting karyawan terhadap penilaian kinerja adalah kepuasan karyawan pada penilaian kinerja 


\section{Masrukin}

\section{Musa Hubeis}

Hari Wijayanto

yang diterapkan oleh perusahaan (Jawahar, 2007). Palaiologos et al. (2011) menyatakan bahwa kepuasan penilaian kinerja memainkan peranan penting dalam pengembangan perilaku kerja dan keorganisasian yang baik dan meningkatkan motivasi untuk peningkatan kinerja.

Kepuasan penilaian kinerja terdiri atas tiga dimensi, yaitu kepuasan terhadap nilai, kepuasan terhadap penilai dan kepuasan terhadap umpan balik (Jawahar, 2007; Palaiologos et al., 2011; Ibeogu \& Ozturen, 2015). Kepuasan terhadap nilai adalah respon karyawan terhadap nilai yang diperoleh karyawan dalam penilaian kinerja. Nilai merupakan wujud umpan balik dari penilaian kinerja dan nilai sering digunakan dalam keputusankeputusan administratif. Nilai dan keputusan yang dibuat atas nilai tersebut merupakan hal yang penting bagi karyawan, sehingga nilai yang tinggi akan memuaskan karyawan (Jawahar, 2007).

Kepuasan penilaian juga ditentukan oleh respon karyawan terhadap penilai atau atasannya. Dalam penilaian kinerja, penilai memiliki peran sangat penting, karena penilai mengevaluasi kinerja dan memberikan umpan balik terkait dengan kinerja kepada karyawan. Karyawan lebih puas dengan penilai atau atasan yang memiliki sensitifitas dalam hubungan interpersonal, memberikan penjelasan memadai tentang prosedur penilaian kinerja, rasional dalam melakukan penilaian kinerja, dan menyampaikan semua informasi terkait penilaian kinerja dengan benar dan jujur (Jawahar, 2007).

Umpan balik penilaian adalah tanggapan balik penilaian kinerja yang diberikan kepada karyawan. Menurut Jawahar (2007), umpan balik penilaian penting bagi karyawan dan organisasi. Hal ini dapat dipahami bahwa umpan balik memiliki pengaruh pada kinerja karyawan dan perilaku ketertarikan kepada organisasi. Berdadarkan sudut pandang organisasi, umpan balik mengarahkan karyawan kepada tujuan organisasi dan menstimulasi dan memelihara semangat kerja yang tinggi. Berdasarkan sudut pandang karyawan, umpan balik penilaian memberikan informasi tentang cara mencapai tujuan pribadinya, serta kebutuhan informasi tentang perbandingan relatif kinerjanya dengan kinerja orang lain. Umpan balik tidak hanya berupa penyampaian nilai kepada karyawan, namun lebih luas lagi meliputi tinjauan ulang terhadap kinerja yang telah dicapai, penghargaan atas keberhasilan dan identifikasi area perbaikan kinerja di masa depan. 


\section{Kinerja}

Amir (2015) berpendapat bahwa kinerja adalah perilaku atau kegiatan yang ditampilkan oleh seseorang dalam kaitannya dengan tugas kerja di perusahaan, departemen, atau organisasi, dilaksanakan sesuai dengan potensi yang dimilikinya, dalam rangka menghasilkan sesuatu yang bermakna bagi organisasi, masyarakat luas atau bagi diri sendiri. Menurut Aguinis (2014), kinerja adalah apa yang dilakukan karyawan (behaviour) dan bukan apa yang dihasilkan oleh karyawan dalam pekerjaannya.

Kinerja (work performance) memiliki tiga dimensi, yakni task performance, contextual performance dan counterproductive behaviour. Task performance adalah kecakapan dalam melaksanakan tugas pokok sesuai job description. Contextual performance adalah perilaku individu yang mendukung lingkungan organisasional, sosial dan psikologis sehingga tugas-tugas teknis inti dapat dijalankan. Counterproductive behavior adalah perilaku karyawan yang dapat mengganggu kinerja organisasi meliputi: perilaku seperti ketidakhadiran, terlambat bekerja, meninggalkan pekerjaan, pencurian, dan mabuk dalam kerja (Koopmans et al., 2014). Diantara ketiga dimensi tersebut, task performance merupakan dimensi penting dari kinerja individu karena dimensi ini digunakan oleh banyak peneliti (dengan label yang berbeda, antara lain: job-specific task proficiency, technical proficiency, in-role performance) dan merupakan fokus penelitian-penelitian tentang kinerja individu (Koopmans et al., 2011). Berdasarkan hal-hal tersebut, maka penelitian ini memfokuskan pada dimensi task performance untuk peubah kinerja yang diamati.

\section{Pengaruh Keadilan Organisasi dalam Penilaian Kinerja terhadap Kepuasan Penilaian Kinerja}

Keadilan organisasi menyediakan kerangka teori yang kuat untuk menjelaskan persepsi keadilan dalam penilaian kinerja. Teori keadilan organisasi berakar pada teori pertukaran sosial (social exchange theory) dan teori keadilan (equity theory) (Thurston \& McNall, 2010). Berdasarkan teori pertukaran sosial (Roch \& Shanock, 2006) dan teori keadilan (Adams, 1963), penilaian kinerja merupakan proses pertukaran kontribusi yang diberikan karyawan dengan imbalan yang diperoleh dari organisasi. Karyawan membandingkan hasil yang diperoleh dengan kontribusi yang diberikan kepada organisasi dengan hasil dan kontribusi orang lain. Jika perbandingan tersebut wajar, maka karyawan merasakan adanya keadilan organisasi dan akan merasa puas dengan pertukaran tersebut (Thurston \& McNall, 2010). Temuan-temuan empiris dari kajian penelitian terdahulu menunjukkan keadilan organisasi berhubungan dengan aspek-aspek kepuasan penilaian kinerja (Thurston \& McNall, 2010; Palaiologos et al., 2011; Kaleem et al., 2013; Warokka et al., 2012 dan Fauziah, 2015). Berdasarkan landasan teoritis dan hasil penelitian-penelitian empiris, maka disusun hipotesis pertama penelitian sebagai berikut:

\section{$H_{1}$ : Keadilan organisasi berpengaruh terhadap kepuasan penilaian kinerja}




\section{Masrukin}

\section{Musa Hubeis \\ Hari Wijayanto}

\section{Pengaruh Kepuasan Penilaian Kinerja terhadap Kinerja}

Kuvaas (2006) dan Katavich (2013) menyatakan teori yang dapat menjelaskan hubungan penilaian kinerja dengan kinerja adalah teori penetapan tujuan (goal setting theory). Sesuai teori penetapan tujuan (goal setting theory), penilaian kinerja yang memenuhi aspek-aspek keadilan organisasi, yakni memberikan tujuan-tujuan spesifik berupa standar kinerja yang harus dicapai, perumusan standar kerja dengan partisipasi karyawan dan adanya umpan balik yang tepat dari atasan dengan interaksi yang baik, akan memberikan kepuasan terhadap penilaian kinerja yang meningkatkan motivasi kerja dan akhirnya berpengaruh positif pada kinerja karyawan.

Beberapa penelitian terdahulu mengkonfirmasi adanya hubungan kepuasan penilaian kinerja dengan kinerja (Blau, 1999; Fakhimi \& Raisy, 2013; Fauziah, 2015; Kaleem et al., 2013). Blau (1999) menemukan hubungan tak langsung kepuasan penilaian kinerja terhadap kinerja karyawan bahwa kepuasan penilaian kinerja berhubungan positif dengan kepuasan kerja dan kepuasan kerja berhubungan positif dengan kinerja. Fakhimi \& Raisy (2013) menemukan kepuasan penilaian kinerja memiliki pengaruh moderat terhadap kinerja karyawan. Fauziah (2015) menemukan kepuasan penilaian kinerja berpengaruh nyata terhadap kinerja. Kaleem et al. (2013) menemukan kepuasan penilaian kinerja berhubungan nyata dan positif dengan kinerja. Berdasarkan tinjauan teoritis dan kajian penelitian terdahulu yang telah diuraikan, maka disusun hipotesis kedua penelitian sebagai berikut:

\section{$\mathrm{H}_{2}$ : Kepuasan penilaian kinerja berpengaruh terhadap kinerja}

\section{Pengaruh Keadilan Organisasi dalam Penilaian Kinerja terhadap Kinerja}

Teori pertukaran sosial (social exchange theory) menjelaskan jika dua pihak atau lebih melakukan hubungan timbal balik, maka masing-masing pihak akan mendapatkan keuntungan dari hubungan tersebut (Roch \& Shanock, 2006). Secara konteks penilaian kinerja, jika penilaian kinerja dirasakan adil oleh karyawan, maka karyawan akan membalas niat baik organisasi dengan kinerja lebih baik di masa depan (Kuvaas, 2006; Katavich, 2013). Bukti empiris pada penelitian terdahulu menemukan bahwa keadilan organisasi dalam penilaian kinerja berpengaruh terhadap kinerja (labal et al., 2017). Nasurdin \& Khuan (2013) menemukan bahwa keadilan organisasi merupakan motivator penting bagi kinerja karyawan. Keadilan organisasi dalam penilaian kinerja berpengaruh terhadap kinerja melalui mediasi kepuasan penilaian kinerja ditemukan oleh Kaleem et al. (2013) dan Fauziah (2015). Berdasarkan uraian ini, maka hipotesis ketiga dan keempat penelitian ini adalah;

\section{$\mathrm{H}_{3}$ : Keadilan organisasi berpengaruh terhadap kinerja karyawan}


$\mathrm{H}_{4}$ : Kepuasan penilaian kinerja memediasi pengaruh kepuasan penilaian kinerja terhadap kinerja

Tinjauan literatur memberikan landasan berpikir untuk menyusun kerangka pemikiran penelitian tentang pengaruh keadilan organisasi dalam penilaian kinerja terhadap kepuasan penilaian dan kinerja. Kerangka pemikiran penelitan ini disajikan oleh Gambar 1.

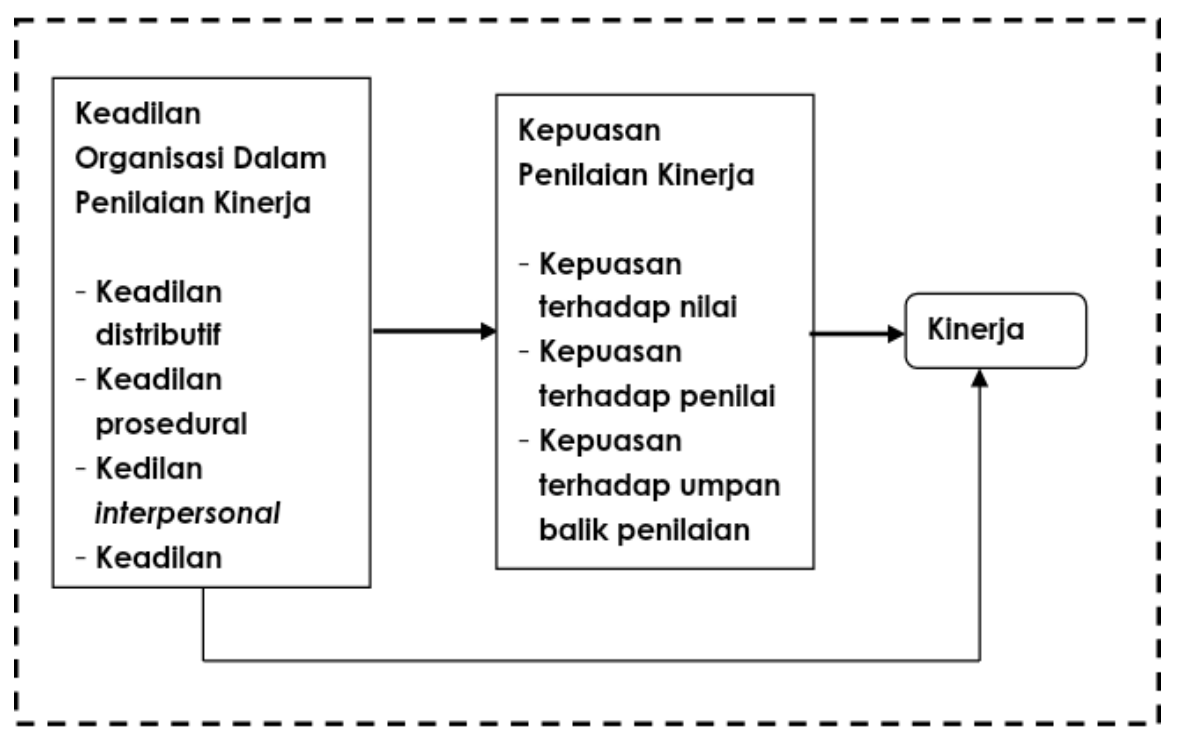

Gambar 1. Kerangka Pemikiran Penilitian

\section{METODE PENELITIAN}

Peubah atau variabel penelitian ini terdiri atas peubah independen, dependen dan perantara. Peubah independen adalah keadilan organisasi dalam penilaian kinerja, peubah dependen adalah kinerja dan perubah perantara adalah kepuasan penilaian kinerja. Peubah keadilan organisasi diukur dengan empat dimensi, yakni keadilan distributif (DJ) dengan empat indikator, keadilan prosedural (PJ) dengan tujuh indikator, keadilan interpersonal (ITJ) dengan empat indikator dan keadilan informasional (IFJ) dengan lima indikator. Semua indikator peubah keadilan organisasi dalam penilaian kinerja diadopsi dari Colquitt (2001). Peubah kepuasan penilaian kinerja terdiri atas tiga dimensi, yakni kepuasan nilai (RAT) dengan dua indikator, kepuasan penilai dengan tiga indikator dan kepuasan umpan balik dengan tiga indikator (Jawahar, 2007). Peubah kinerja diukur dengan lima indikator kinerja tugas (task performance) yang diadopsi dari Koopmans et al. (2014). Semua indikator penelitian diukur dengan skala likert 1-5.

Penelitian dilaksanakan di PTPN V Pekanbaru yang melibatkan responden sebanyak 196 karyawan manajerial dari seluruh level jabatan (top manager, middle manager dan supervisor) yang berasal dari populasi karyawan manajerial berjumlah 500 orang. 


\section{Masrukin}

\section{Musa Hubeis}

\section{Hari Wijayanto}

Pengumpulan data menggunakan kuesioner online dan wawancara responden. Teknik pengambilan contoh atau sampel dengan purposive sampling. Data dianalisis dengan metode statistik deskriptif dan inferensial. Statistik deskriptif meliputi deskripftif responden, analisis nilai rataan dan analisis rentang kriteria. Analisis inferensial yang digunakan adalah analisis statistik multivariat dengan analisis Structural Equation Modelling (SEM) pendekatan Partial Least Square (PLS) dengan software SmartPLS 3.2.7.

\section{HASIL DAN PEMBAHASAN}

\section{Karakteristik Responden}

Karakteristik responden yang dikaji pada penelitan ini adalah karakteristik demografi, yakni faktor biografi (jenis kelamin, usia dan pendidikan) dan faktor pekerjaan (level jabatan, tipe pekerjaan dan masa kerja).

\section{Faktor Biografi}

Responden didominasi oleh karyawan dengan jenis kelamin laki-laki, sesuai dengan sifat pekerjaan di perusahaan perkebunan yang didominasi oleh pekerjaan diluar ruangan dan membutuhkan tenaga fisik. Berdasarkan usia, responden sebagian besar tergolong dalam tenaga kerja dengan usia produktif (< 50 tahun) yang merupakan modal SDM potensial untuk mendukung tujuan perusahaan. Berdasarkan latar belakang pendidikan, responden sebagian besar adalah karyawan dengan latar belakang pendidikan tinggi (Diploma, S1 dan S2) yang relevan dengan tugas dan tanggung jawabnya sebagai karyawan manajerial. Karyawan manajerial dengan latar belakang SMA sederajat adalah karyawan manajerial yang bersumber dari promosi jabatan karyawan non manajerial. Karakteristik faktor biografi responden disajikan oleh Tabel 1.

Tabel 1. Karakteristik faktor biografi responden

\begin{tabular}{ccc}
\hline Karakteristik & Responden & Persentase \\
\hline \multicolumn{3}{c}{ Jenis Kelamin } \\
\hline Laki-laki & 182 & 91.8 \\
Perempuan & 14 & 8.2 \\
Jumlah & 196 & 100 \\
\hline \multicolumn{3}{c}{ Usia (tahun) } \\
\hline $21-30$ & 17 & 8.81 \\
$31-40$ & 49 & 25.39 \\
$41-50$ & 98 & 50.78 \\
$>50$ & 29 & 15.03 \\
Jumlah & $193 a$ \\
\hline \multicolumn{3}{c}{100} \\
\hline S2 & Pendidikan \\
S1 & 26 & 13.27 \\
Diploma & 135 & 68.88 \\
SMA sederajat & 8 & 4.08 \\
Jumlah & 27 & 13.78 \\
\hline a: Tiga responden tidak menyampaikan data usia
\end{tabular}




\section{Faktor Pekerjaan}

Level jabatan karyawan manajerial di PTPN $\vee$ terdiri atas tiga tingkatan, yakni top manager, middle manager dan supervisor. Top manager adalah karyawan yang menduduki pimpinan puncak dari uni-unit kerja dan bagian-bagian di kantor pusat yang menjalankan fungsi pengambil keputusan dan penanggungjawab utama di unit kerja/bagian. Middle manager adalah karyawan yang menjalankan fungsi eksekutor, yakni pelaksana langsung keputusankeputusan top manager yang membawahi karyawan-karyawan supervisor. Supervisor adalah karyawan yang memimpin sub-sub unit kerja/sub bagian/sub bidang Distrik yang membawahi langsung karyawan pelaksana.

Berdasarkan tipe pekerjaan, jabatan karyawan manajerial di PTPN $\vee$ dapat dibagi menjadi dua kategori, yakni jabatan operasional dan supporting. Jabatan operasional adalah jabatan-jabatan karyawan manajerial yang berhubungan langsung dengan operasional bisnis inti perusahaan di unit-unit kerja kebun dan pabrik. Jabatan dengan fungsi supporting adalah jabatan-jabatan karyawan manajerial yang menjalankan fungsi pendukung dari fungsi-fungi operasional dan kegiatan administratif perusahaan di kantor pusat dan kantor Distrik.

Berdasarkan masa kerja, responden penelitian telah memenuhi persyaratan sebagai contoh penelitian yakni masa kerja minimal tiga tahun atau responden telah mendapatkan penilaian kinerja tahunan minimal dua kali sehingga responden dapat memberikan tanggapan atas persepsi tentang penilaian kinerja. Karakteristik pekerjaan responden dimuat pada Tabel 2.

Tabel 2. Karakteristik pekerjaan responden

\begin{tabular}{ccc}
\hline Karakteristik Pekerjaan & Responden & Persentase \\
\hline & Level Jabatan \\
\hline Top Manager & 24 & 12.37 \\
Middle Manager & 57 & 29.38 \\
Supervisor & 113 & 58.25 \\
Jumlah & $\mathbf{1 9 4}$ b & $\mathbf{1 0 0}$ \\
\hline \multicolumn{3}{c}{ Tipe Pekerjaan } \\
\hline Operasional & 93 & 47.94 \\
Supporting & 101 & 52.06 \\
Jumlah & $\mathbf{1 9 4}$ Masa Kerja (tahun) \\
\hline$<5$ & 46 & 100 \\
\hline $5-10$ & 32 & 23.47 \\
$>10$ & 118 & 60.20 \\
\hline Jumlah & $\mathbf{1 9 6}$ \\
\hline b: Dua responden tidak menyampaikan data jabatan
\end{tabular}




\section{Masrukin}

\section{Musa Hubeis \\ Hari Wijayanto}

Berdasarkan gambaran karakteristik responden pada Tabel 1 dan Tabel 2 dapat dilihat bahwa responden telah memiliki keterwakilan contoh yang baik, karena setiap kategori sudah terwakili dan mendekati gambaran populasinya

\section{Persepsi Keadilan Organisasi dalam Penilaian Kinerja}

Persepsi adalah proses karyawan mengorganisasikan dan menginterpretasikan kesan yang diperoleh dari lingkungannya (Robbins \& Judge, 2016), yaitu penilaian kinerja yang diterapkan perusahaan. Persepsi karyawan tentang keadilan organisasi dalam penilaian kinerja dinyatakan dengan nilai rataan masing-masing dimensi keadilan dari jawaban responden. Persepsi karyawan terhadap keadilan organisasi dalam penilaian kinerja dimuat pada Tabel 3. Kriteria tingkatan persepsi keadilan didasarkan pada kategori kualitatif yang ditetapkan berdasarkan rumus berikut:

$$
\mathrm{RK}=(\mathrm{m}-\mathrm{n}) / \mathrm{k}
$$
RK: rentang kelas
m: nilai skala jawaban responden tertinggi (=5)
n: nilai skala jawaban responden terendah (=1)
k: jumlah kelas (=3 kelas)

Tabel 3. Persepsi keadilan organisasi dalam penilaian kinerja

\begin{tabular}{lcl}
\hline \multicolumn{1}{c}{ Keadilan Organisasi } & Nilai & \multicolumn{1}{c}{ Kriteria } \\
\hline Keadilan Distributif & 4.00 & Tinggi \\
Keadilan Prosedural & 3.66 & Sedang \\
Keadilan Interpersonal & 4.25 & Tinggi \\
Keadilan Informasional & 4.00 & Tinggi \\
\hline Kriteria : Rendah (1.00-2.33); Sedang (2.34-3.66); Tinggi (3.67-5.00)
\end{tabular}

Berdasarkan Tabel 3, secara umum keadilan organisasi dalam penilaian kinerja telah dinilai tinggi. Hasil ini menunjukkan penilaian kinerja yang dilaksanakan telah memenuhi aspekaspek keadilan organisasi. Keadilan distributif memilki nilai persepsi tinggi menunjukkan karyawan merasa distribusi hasil penilaian kinerja telah sesuai dengan usaha yang dilakukan, penyelesaian pekerjaan, kinerja yang dicapai dan kontribusi karyawan dalam perusahaan. Keadilan prosedural memiliki nilai sedang yang menunjukkan pelaksanaan prosedur pendistribusian hasil penilaian masih belum sepenuhnya memenuhi harapan karyawan. Indikator-indikator keadilan prosedural yang dirasakan kurang oleh karyawan adalah keterlibatan dalam penyusunan standar kinerja, masih adanya bias penilaian dan kurangnya kesempatan dalam penyampaian keberatan terhadap hasil penilaian kinerja. Keadilan interpersonal memiliki nilai rataan tertinggi yang menunjukkan hubungan interpersonal antara atasan penilai (rater) dengan karyawan (ratee) telah baik (Wibowo, 
2013). Menurut Thurston \& McNall (2010), keadilan interpersonal yang tinggi memberi kontribusi besar terhadap persepsi keadilan organisasi dalam penilaian kinerja secara keseluruhan, sehingga karyawan dapat menerima kekurangan pada dimensi keadilan lainnya. Persepsi keadilan informasional memiliki nilai tinggi menunjukkan atasan telah memberikan informasi yang jelas tentang prosedur, proses dan hasil penilaian kinerja kepada karyawan, sehingga karyawan memahami penilaian kinerja yang diterapkan pada dirinya.

\section{Persepsi Kepuasan Penilaian Kinerja}

Analisis deskriptif persepsi responden terhadap kepuasan penilaian kinerja disajikan oleh Tabel 4.

Tabel 4. Persepsi kepuasan penilaian kinerja

\begin{tabular}{lcc}
\hline Kepuasan penilaian kinerja & Nilai & Kriteria \\
\hline Kepuasan nilai & 4.04 & Tinggi \\
Kepuasan penilai & 4.27 & Tinggi \\
Kepuasan umpan balik & 3.96 & Tinggi \\
\hline \multicolumn{2}{l}{ Kriteria : Rendah (1.00-2.33); Sedang (2.34-3.66); Tinggi (3.67-5.00) }
\end{tabular}

Persepsi responden terhadap kepuasan penilaian kinerja berada pada kriteria tinggi. Hal ini menunjukkan karyawan telah puas dengan penilaian kinerja yang diterapkan oleh manajemen PTPN V. Karyawan yang memberikan nilai tinggi menunjukkan karyawan telah puas dan menerima nilai kinerja tahunannya. Kepuasan terhadap penilai (atasan) tinggi karena karyawan merasa atasan memberi bantuan, dukungan dan arahan dalam mencapai kinerja dan atasan memahami pekerjaan bawahan dengan baik. Kepuasan terhadap umpan balik adalah kepuasan terhadap evaluasi tahunan penilaian kinerja, kepuasan atas penghargaan yang diberikan kepuasan atas penjelasan-penjelasan area perbaikan kinerja. Meskipun persepsi kepuasan umpan balik telah tergolong dalam kategori tinggi, namun nilai kepuasannya terendah dibandingkan dengan kepuasan lainnya sehingga layak menjadi perhatian manajemen.

\section{Analisis SEM}

Menurut Santosa (2018), SEM adalah teknik statistik multivariat yang merupakan kombinasi antara analisis faktor dan analisis regresi yang bertujuan untuk menguji hubungan-hubungan antar peubah yang ada pada sebuah model, baik itu antara indikator dengan kontruknya maupun hubungan antar kontruk. Analisis SEM yang digunakan pada penelitian ini adalah SEM dengan pendekatan PLS mengingat data tidak berdistribusi normal. Latan \& Ghozali (2012) menyatakan SEM-PLS cocok digunakan untuk data yang berdistribusi tidak normal (distribution free). Analisis SEM terdiri atas: evaluasi model pengukuran, evaluasi model 


\section{Masrukin}

\section{Musa Hubeis}

\section{Hari Wijayanto}

struktural, evaluasi goodness of fit model dan pengujian hipotesis. Model pengukuran dan struktural hasil pengolahan SmartPLS disajikan pada Gambar 1.

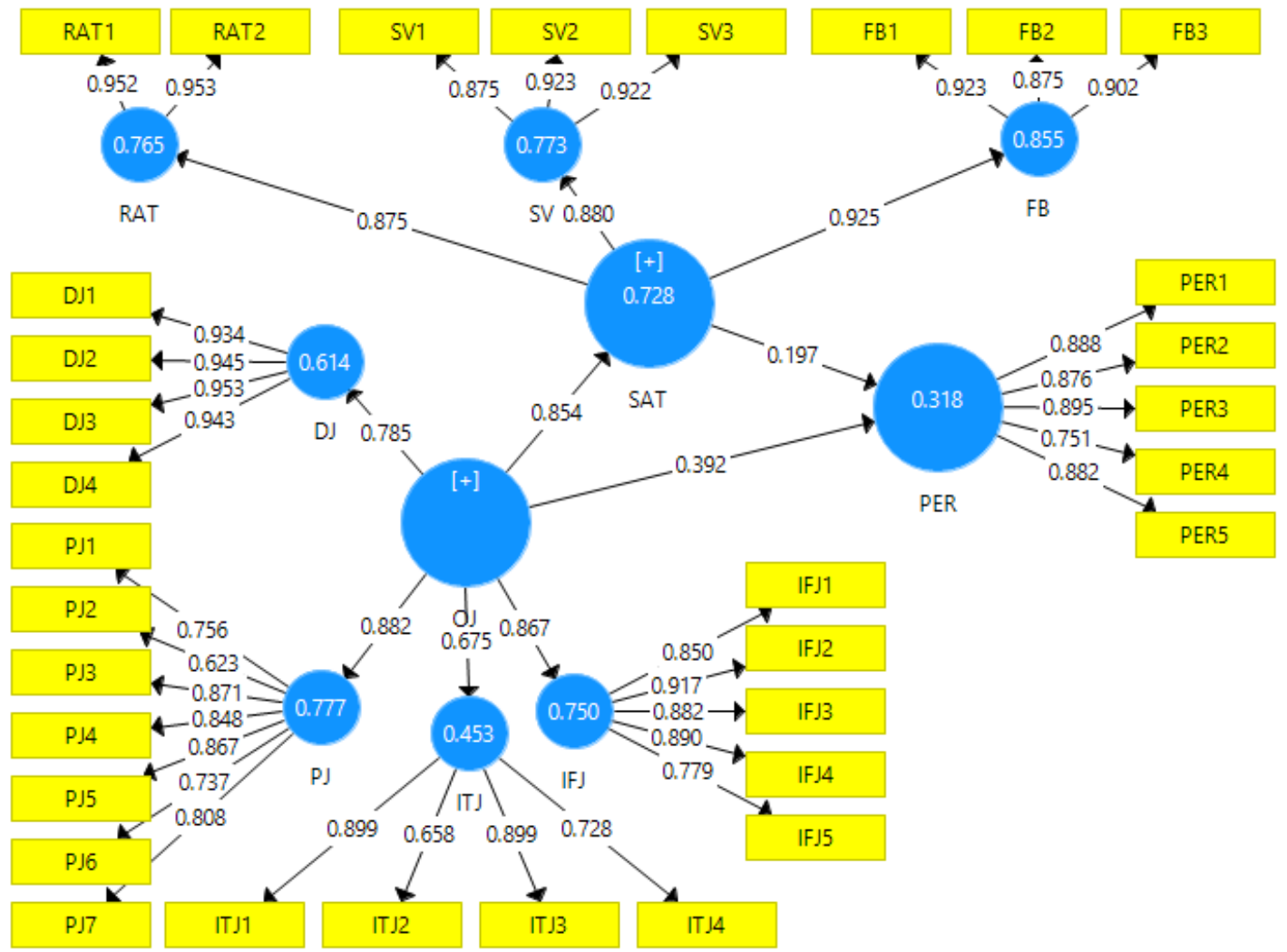

Gambar 2. Model pengukuran dan model struktural hasil pengolahan SEM-PLS

\section{Keterangan:}

$\begin{array}{lll}\text { OJ } & : \text { organizational justice adalah peubah laten keadilan organisasi } \\ \text { SAT } & : \text { satisfaction adalah peubah laten kepuasan penilaian kinerja } \\ \text { PER } & : \text { performance adalah peubah laten kinerja } \\ \text { DJ } & : \text { distributive justice adalah peubah keadilan distributif } \\ \text { PJ } & : \text { procedural justice adalah peubah keadilan prosedural } \\ \text { ITJ } & : \text { interpersonal justice adalah peubah keadilan interpersonal } \\ \text { IFJ } & : \text { informasional justice adalah peubah keadilan informasional } \\ \text { RAT } & : \text { rating adalah peubah laten kepuasan terhadap nilai } \\ \text { SV } & : \text { supervisor adalah peubah laten kepuasan terhadap penilai } \\ \text { FB } & : \text { feedback adalah peubah laten kepuasan terhadap umpan balik } \\ \text { DJ1-DJ4 } & : \text { indikator pengukur peubah keadilan distributif } \\ \text { PJ1-PJ7 } & : \text { indikator pengukur peubah keadilan prosedural } \\ \text { ITJ1-ITJ4 } & : \text { indikator pengukur peubah keadilan interpersonal } \\ \text { IFJ1-IFJ5 } & : \text { indikator pengukur peubah keadilan informasional } \\ \text { RAT1-RAT2 } & : \text { indikator pengukur peubah kepuasan terhadap nilai } \\ \text { SV1-SV3 } & : \text { indikator pengukur peubah kepuasan terhadap penilai } \\ \text { FB1-FB3 } & : \text { indikator pengukur peubah kepuasan terhadap umpan balik } \\ \text { PER1-PER5 } & : \text { indikator pengukur peubah kinerja }\end{array}$




\section{Evaluasi Model Pengukuran}

Berdasarkan analisis SEM, evaluasi model pengukuran bertujuan menguji validitas dan reliabilitas indikator-indikator penelitian. Validitas ditentukan dari nilai loading factor dan nilai AVE (average variance extracted) dengan ketentuan nilai loading factor minimal 0.5 dan nilai AVE minimal 0.5 (Latan \& Ghozali, 2012). Hasil pengolahan menghasilkan nilai loading factor sesuai Gambar 1 dan nilai AVE yang disajikan pada Tabel 5. Gambar 1 dan Tabel 5 menunjukkan semua indikator penelitian memiliki nilai loading factor $>0.6$ dan nilai AVE > 0.5 , sehingga seluruh indikator dinyatakan valid.

\section{Tabel 5. Nilai AVE peubah laten penelitian}

\begin{tabular}{lccc}
\hline \multicolumn{1}{c}{ Uraian } & AVE & Syarat & Keterangan \\
\hline Keadilan Organisasi & 0.529 & $>0.5$ & Memenuhi \\
Keadilan Distributif & 0.891 & $>0.5$ & Memenuhi \\
Keadilan Prosedural & 0.626 & $>0.5$ & Memenuhi \\
Keadilan Interpersonal & 0.645 & $>0.5$ & Memenuhi \\
Keadilan Informasional & 0.748 & $>0.5$ & Memenuhi \\
Kepuasan Penilaian Kerja & 0.673 & $>0.5$ & Memenuhi \\
Kepuasan nilai & 0.907 & $>0.5$ & Memenuhi \\
Kepuasan penilai & 0.823 & $>0.5$ & Memenuhi \\
Kepuasan umpan balik & 0.810 & $>0.5$ & Memenuhi \\
Kinerja & 0.739 & $>0.5$ & Memenuhi \\
\hline
\end{tabular}

Reliabilitas dalam analisis SEM diukur berdasarkan nilai croanbach's alpha dan reliabilitas komposit dengan ketentuan nilai croanbach's alpha $>0.7$ dan reliabilitas komposit $>0.7$ (Latan \& Ghozali, 2012). Hasil pengolahan data menghasilkan nilai croanbach's alpha dan reliabilitas komposit yang dimuat pada Tabel 6.

Tabel 6. Nilai cronbach's alpha dan reliabilitas komposit peubah laten penelitian

\begin{tabular}{lccccc}
\hline \multicolumn{1}{c}{ Uraian } & $\begin{array}{c}\text { Cronbach's } \\
\text { alpha }\end{array}$ & Syarat & $\begin{array}{c}\text { Reliabilitas } \\
\text { Komposit }\end{array}$ & Syarat & Keterangan \\
\hline Keadilan Organisasi & 0.944 & $>0.7$ & 0.950 & $>0.7$ & Memenuhi \\
Keadilan Distributif & 0.959 & $>0.7$ & 0.970 & $>0.7$ & Memenuhi \\
Keadilan Prosedural & 0.899 & $>0.7$ & 0.921 & $>0.7$ & Memenuhi \\
Keadilan Interpersonal & 0.811 & $>0.7$ & 0.877 & $>0.7$ & Memenuhi \\
Keadilan Informasional & 0.915 & $>0.7$ & 0.937 & $>0.7$ & Memenuhi \\
Kepuasan Penilaian Kerja & 0.930 & $>0.7$ & 0.943 & $>0.7$ & Memenuhi \\
Kepuasan nilai & 0.898 & $>0.7$ & 0.951 & $>0.7$ & Memenuhi \\
Kepuasan penilai & 0.892 & $>0.7$ & 0.933 & $>0.7$ & Memenuhi \\
Kepuasan umpan balik & 0.883 & $>0.7$ & 0.928 & $>0.7$ & Memenuhi \\
Kinerja & 0.911 & $>0.7$ & 0.934 & $>0.7$ & Memenuhi \\
\hline
\end{tabular}




\section{Masrukin}

\section{Musa Hubeis}

\section{Hari Wijayanto}

Tabel 6 menunjukkan semua peubah laten penelitian telah memenuhi syarat, yakni nilai croanbach's alpha $>0.7$ dan reliabilitas komposit $>0.7$, sehingga seluruh peubah laten penelitian dinyatakan reliabel.

\section{Evaluasi Model Struktural}

Evaluasi model struktural dilakukan dengan kriteria nilai determinasi ( $R^{2}$-adjusted) dan nilai predictive relevance $\left(Q^{2}\right)$. Ketentuan yang digunakan adalah nilai $R^{2}=0.67$ adalah model kuat, $R^{2}=0.33$ adalah model sedang dan $R^{2}=0.19$ adalah model lemah. Nilai $Q^{2}$ memiliki rentang nilai 0-1, nilai mendekati 1 menunjukkan model memiliki predictive relevance (Latan \& Ghozali, 2012). Hasil pengolahan data menggunakan sofware SmartPLS 3.2.7. menghasilkan nilai $R^{2}$ dan $Q^{2}$ yang disajikan oleh Tabel 7 dan 8.

Tabel 7. Nilai $\mathbf{R}^{2}$ model struktural

\begin{tabular}{lccc}
\hline \multicolumn{1}{c}{ Peubah laten } & $\boldsymbol{R}^{\mathbf{2}}$-Square (Adjusted) & Kriteria & Kategori \\
\hline Kepuasan penilaian kinerja & 0.728 & $>0.67$ & Kuat \\
Kinerja & 0.318 & 0.33 & Sedang \\
\hline
\end{tabular}

Tabel 8. Nilai $Q^{2}$ model struktural

\begin{tabular}{lccc}
\hline \multicolumn{1}{c}{ Peubah laten } & SSO & SSE & Q $^{2}$ (=1-SSE/SSO) \\
\hline Kepuasan Penilaian Kinerja & 1.568 & 832,317 & 0.469 \\
Kinerja & 980 & 760,824 & 0.224 \\
\hline
\end{tabular}

Berdasarkan Tabel 7 , nilai $R^{2}$ peubah-peubah laten penelitian termasuk dalam kriteria sedang sampai kuat yang menunjukkan peubah eksogen dapat menjadi penjelas yang baik varian peubah-peubah endogennya. Nilai $R^{2}$ merupakan besarnya varian peubah endogen yang mampu dijelaskan oleh peubah eksogennya. Peubah endogen pertama, yakni kepuasan penilaian kinerja, memiliki nilai $R^{2} 0.728$. Hal ini berarti bahwa $72.8 \%$ varian kepuasan penilaian kinerja dapat dijelaskan oleh peubah eksogen keadilan organisasi dalam penilaian kinerja dan sisanya (27.2\%) dijelaskan oleh peubah-peubah lain yang tidak terdapat dalam model. Peubah endogen kedua, yakni kinerja, memiliki nilai $R^{2} 0.318$. Hal ini berarti $31.8 \%$ varian peubah kinerja disebabkan secara bersama-sama oleh peubah eksogen keadilan organisasi dan kepuasan penilaian kinerja, sedangkan sisanya (68.2\%) dijelaskan oleh peubah-peubah lain yang tidak terdapat dalam model. Tabel 8 menunjukkan nilai $Q^{2}$ semua peubah laten penelitian > 0 . Hal ini mengindikasikan bahwa model struktural memiliki predictive relevance yang baik. 


\section{Evaluasi Goodness of Fit Model}

Tahap evaluasi model yang terakhir adalah evaluasi model secara keseluruhan dengan kriteria nilai Gof (Goodness of fit). Ketentuan nilai Gof adalah 0-1, nilai Gof mendekati 1 menunjukkan model yang baik (fit). Nilai Gof dihitung dengan persamaan berikut:

$$
G o F=\sqrt{\underline{A V E} \times \underline{R^{2}}}
$$

$\underline{A V E}$ adalah rataan dari semua nilai AVE masing-masing peubah laten dan $\underline{R^{2}}$ adalah rataan nilai $R^{2}$ untuk semua peubah laten endogen (Latan H \& Ghozali I., 2012). Perhitungan indeks GoF menggunakan persamaan tersebut diperoleh hasil GoF sebesar 0.704. Nilai indeks Gof mendekati 1 menunjukkan model fit dan dapat digunakan untuk pengujian hipotesis penelitian.

\section{Pengujian Hipotesis Penelitian}

Uji hipotesis dalam analisis SEM-PLS dilakukan melalui prosedur bootstrapping. Statistik uji untuk pengujian hipotesis adalah nilai t-hitung dan $\mathrm{p}$-value dengan titik kritis penolakan Ho adalah t-hitung $>1.96$ dan $\mathrm{p}$-value $<0.05$. Hasil pengolahan prosedur bootstrapping disajikan pada Tabel 9.

\section{Tabel 9. Hasil pengolahan prosedur bootstraaping dengan SmartPLS}

\begin{tabular}{|c|c|c|c|c|c|c|}
\hline \multirow[t]{2}{*}{ Hipotesis Penelitian } & \multirow{2}{*}{$\begin{array}{l}\text { Loading } \\
\text { factor }\end{array}$} & \multirow{2}{*}{ t-hitung } & \multirow{2}{*}{ p-hitung } & \multicolumn{2}{|c|}{$\begin{array}{c}\text { Titik Kritis Penolakan } \\
\mathrm{H}_{0} \\
\end{array}$} & \multirow{2}{*}{$\begin{array}{c}\text { Hasil } \\
\text { Pengujian }\end{array}$} \\
\hline & & & & t-tabel & Sign. & \\
\hline $\begin{array}{l}\mathrm{H}_{1} \text { : } \text { Pengaruh keadilan organisasi } \\
\quad \text { terhadap kepuasan penilaian } \\
\text { kinerja }\end{array}$ & 0.854 & 33,348 & 0,000 & $>1.96$ & $<0.05$ & $\mathrm{Hl}$ diterima \\
\hline $\begin{array}{l}\mathrm{H}_{2} \text { : Pengaruh kepuasan penilaian } \\
\text { kinerja terhadap kinerja }\end{array}$ & 0.197 & 1,127 & 0,260 & $>1.96$ & $<0.05$ & H2 ditolak \\
\hline $\begin{array}{l}\mathrm{H}_{3}: \text { Pengaruh keadilan organisasi } \\
\text { terhadap kinerja }\end{array}$ & 0.392 & 2,367 & 0,018 & $>1.96$ & $<0.05$ & H3 diterima \\
\hline
\end{tabular}

\section{Pengaruh Keadilan Organisasi dalam Penilaian Kinerja terhadap Kepuasan Penilaian Kinerja}

Hasil pengolahan data sesuai Tabel 9 menunjukkan pengaruh keadilan organisasi terhadap kepuasan penilaian kinerja memiliki nilai t-hitung $>1.96$ dan $p$-valve $<0.05$, serta loading factor 0.854. Hasil ini menunjukkan keadilan organisasi dalam penilaian kinerja yang diterapkan oleh manajemen PTPN $\vee$ memiliki pengaruh nyata terhadap kepuasan penilaian kinerja karyawannya. Nilai loading factor 0.854 berarti bahwa setiap kenaikan satu satuan keadilan organisasi akan meningkatkan kepuasan penilaian kinerja 0.854 satuan. Hasil penelitian ini sesuai dengan penelitan Thurston \& McNall (2010), Palaiologos et al. (2011), Kaleem et al. (2013), Warokka et al. (2012), dan Fauziah (2015). 


\section{Masrukin}

\section{Musa Hubeis \\ Hari Wijayanto}

Hasil analisis deskriptif menjelaskan bahwa persepsi karyawan PTPN $\vee$ tentang keadilan organisasi dalam penilaian kinerja berada dalam kriteria tinggi yang menunjukkan karyawan merasa perusahaan telah berlaku adil dalam penilaian kinerja. Sesuai dengan teori keadilan, jika karyawan merasa diperlakukan secara adil dalam pekerjaannya, karyawan akan merasa puas dengan penilaian kinerja tersebut. Berdasarkan hasil penelitian ini, hipotesis pertama $\left(\mathrm{H}_{1}\right)$ keadilan organisasi dalam penilaian kinerja berpengaruh terhadap kepuasan penilaian kinerja dapat diterima.

\section{Pengaruh Kepuasan Penilaian Kinerja terhadap Kinerja}

Hasil analisis deskriptif tentang persepsi kepuasan penilaian kinerja menjelaskan bahwa karyawan merasa puas terhadap penilaian kinerja yang diterapkan perusahaan. Penelitianpenelitian terdahulu oleh Kaleem et al. (2013), Fauziah (2015) dan Fakhimi \& Raisy (2013) menemukan kepuasan penilaian kinerja berpengaruh terhadap kinerja. Hasil pengolahan data penelitian ini menemukan pengaruh peubah kepuasan penilaian kinerja terhadap peubah kinerja memiliki t-hitung $<1.96$ dan $p$-value $>0.05$. Hasil ini menunjukkan kepuasan penilaian kinerja tidak berpengaruh nyata terhadap kinerja. Hasil penelitian ini tidak sesuai dengan penelitan-penelitian terdahulu tersebut diatas. Namun, hasil penelitian ini relevan dengan temuan penelitian oleh Kuvaas (2006), Warokka et al. (2012) dan Katavich (2013) yang menemukan kepuasan penilaian kinerja tidak berpengaruh terhadap kinerja. Berdasarkan hasil penelitian ini, maka hipotesis kedua $\left(\mathrm{H}_{2}\right)$ penelitian ini yakni kepuasan penilaian kinerja berpengaruh terhadap kinerja ditolak.

\section{Pengaruh Keadilan Organisasi dalam Penilaian Kinerja terhadap Kinerja}

Berdasarkan Tabel 10, pengaruh keadilan organisasi dalam penilaian kinerja terhadap kinerja memiliki t-hitung $>1.96$ dan $p$-valve<0.05 dengan nilai loading factor 0.392. Hasil analisis ini menunjukkan keadilan organisasi berpengaruh nyata terhadap kinerja. Nilai loading factor 0.392 menunjukkan setiap kenaikan satu satuan keadilan organisasi dalam penilaian kinerja akan meningkatkan kinerja 0.392 satuan. Penelitian-penelitian terdahulu menyatakan pengaruh keadilan organisasi dalam penilaian kinerja terhadap kinerja dimediasi oleh kepuasan penilaian kinerja (Kaleem et al,. 2013; Fauziah, 2015; Mashi, 2017). Hasil penelitian ini tidak relevan dengan hasil penelitian-penelitian tersebut, namun hasil-hasil penelitian keadilan organisasi secara luas memberikan bukti empiris bahwa terdapat pengaruh langsung nyata keadilan organisasi terhadap kinerja, yakni penelitian oleh Abekah-Nkrumah \& Atinga (2013) dan Suliman (2007). Disamping itu, Nasurdin \& Khuan (2013) menemukan keadilan organisasi merupakan motivator penting bagi peningkatan 
kinerja. Berdasarkan hasil ini, hipotesis penelitian ketiga $\left(\mathrm{H}_{3}\right)$ dapat diterima, yakni keadilan organisasi dalam penilaian kinerja berpengaruh nyata terhadap kinerja.

\section{Peran Mediasi Kepuasan Penilaian Kinerja}

Peubah mediasi adalah peubah yang muncul saat peubah independen mulai memengaruhi peubah dependen dan saat pengaruh peubah independen terasa pada peubah dependen (Sekaran, 2017). Pengujian efek mediasi dalam SEM-PLS dilakukan berdasarkan hasil prosedur bootstrapping (Hadi, 2016; Zhao et al., 2010).

Hal pertama yang dipersyaratkan dalam pengujian mediasi adalah pengaruh langsung (direct effect) peubah eksogen terhadap endogen harus nyata. Keberadaan efek mediasi ditentukan oleh pengaruh tidak langsung (indirect efect). Jika indirect effect tidak nyata, efek mediasi tidak terbukti dan sebaliknya. Hasil bootsrapping untuk pengujian efek mediasi disajikan oleh Tabel 10.

Tabel 10. Hasil pengolahan prosedur bootstrapping pengujian mediasi

\begin{tabular}{lcccccc}
\hline \multicolumn{1}{c}{ Effect } & $\begin{array}{c}\text { Loading } \\
\text { factor }\end{array}$ & t-hitung & p-hitung & \multicolumn{2}{c}{ Titik Kritis } & Hasil \\
\cline { 4 - 6 } & t-tabel & Sign. & Pengujian \\
\hline $\begin{array}{l}\text { Direct effect: } \\
\text { Keadilan organisasi -> kinerja }\end{array}$ & 0.392 & 2.260 & 0.024 & $>1.96$ & $<0.05$ & Nyata \\
$\begin{array}{l}\text { Indirect effect: } \\
\begin{array}{l}\text { Keadilan organisasi -> kepuasan } \\
\text { penilaian kinerja -> kinerja }\end{array}\end{array}$ & 0,168 & 1.068 & 0.286 & $>1.96$ & $<0.05$ & Tidak nyata \\
\hline
\end{tabular}

Tabel 10 menunjukkan, pengaruh langsung (direct effect) keadilan organisasi terhadap peubah kinerja adalah nyata. Hasil ini menunjukkan prasyarat pengujian mediasi terpenuhi. Sedangkan, pengaruh tidak langsung (indirect effect) adalah tidak nyata sehingga dinyatakan bahwa tidak terdapat efek mediasi pada model penelitian. Sesuai klasifikasi tipe mediasi menurut Zhao et al. (2010), tipe efek mediasi dalam model penelitian ini adalah direct only non mediation (pengaruh langsung tanpa mediasi).

Berdasarkan hasil pengujian ini, maka peubah kepuasan penilaian kinerja tidak berperan sebagai mediator pengaruh keadilan organisasi dalam penilaian kinerja terhadap kinerja. Beberapa penelitian terdahulu menemukan pengaruh keadilan organisasi dalam penilaian kinerja terhadap kinerja dimediasi oleh kepuasan penilaian kinerja (Kaleem et al. 2013; Fauziah, 2015; dan Mashi, 2017), sehingga hasil penelitian ini tidak mendukung hasil penelitian-penelitian terdahulu tersebut. Berdasarkan hasil ini, maka hipotesis penelitian $\mathrm{H}_{4}$ ditolak, yakni kepuasan penilaian kinerja tidak berperan memediasi pengaruh keadilan organisasi dalam penilaian kinerja terhadap kinerja kinerja. 


\section{Masrukin}

\section{Musa Hubeis \\ Hari Wijayanto}

Hasil penelitian ini secara umum telah mencapai tujuannya, yakni menganalisis pengaruh keadilan organisasi dalam penilaian kinerja terhadap kepuasan penilaian kinerja dan kinerja. Keadilan organisasi dan kepuasan penilaian kinerja telah dinilai tinggi oleh karyawan. Keberadaan persepsi keadilan organisasi dalam penilaian kinerja yang berdampak pada kepuasan karyawan terhadap penilaian kinerja menunjukkan sistem penilaian kinerja yang diterapkan perusahaan telah mendapatkan penerimaan yang baik oleh karyawan. Kondisi ini membuktikan bahwa penilaian kinerja yang diterapkan perusahaan telah efektif.

Hasil penelitian membuktikan keadilan organisasi dalam penilaian kinerja berpengaruh secara langsung dan nyata terhadap kinerja. Keadilan organisasi dalam penilaian kinerja terbukti berpengaruh terhadap kepuasan penilaian kinerja. Hasil penelitian ini memiliki perbedaan dengan beberapa penelitian terdahulu yang menyatakan bahwa keadilan organisasi membutuhkan mediasi kepuasan penilaian kinerja dalam memengaruhi peubah kinerja (Kaleem et al,. 2013; Fauziah, 2015; dan Mashi, 2017), walaupun pada penelitianpenelitian lain ditemukan adanya pengaruh langsung yang nyata keadilan organisasi terhadap kinerja. Hasil penelitian ini menegaskan pentingnya keadilan organisasi dalam penilaian kinerja yang diterapkan oleh perusahaan, karena hal tersebut telah dibuktikan memiliki pengaruh langsung nyata terhadap kinerja karyawan.

Secara teoritis, teori pertukaran sosial yang merupakan akar teori keadilan organisasi dapat menjelaskan temuan penelitian ini. Menurut teori ini, jika dua pihak atau lebih melakukan hubungan timbal balik, maka masing-masing pihak akan mendapatkan keuntungan dari hubungan tersebut (Roch \& Shanock, 2006). Secara konteks penilaian kinerja, jika penilaian kinerja dirasakan adil oleh karyawan, maka karyawan akan membalas niat baik perusahaan dengan kinerja lebih baik di masa depan Kuvaas (2006) dan Katavich (2013). Temuan penelitian ini menjadi bukti empirik penting pada operasionalisasi teori pertukaran sosial dalam konteks penilaian kinerja pada kasus perusahaan lokasi penelitian.

Hasil penelitian tidak mendukung beberapa penelitian terdahulu tentang pengaruh nyata kepuasan penilaian kinerja terhadap kinerja. Kuvaas (2006) menyatakan pengaruh kepuasan penilaian kinerja terhadap kinerja tidak secara langsung, namun membutuhkan mediasi motivasi instrinsik. Jika motivasi instrinsik tinggi, maka kepuasan penilaian kinerja akan berhubungan dengan kinerja. Namun, jika motivasi intrinsik rendah, maka kepuasan penilaian kinerja tidak berpengaruh terhadap kinerja. Sejalan dengan pendapat ini, Fakhimi \& Raisy (2013) juga menyatakan bahwa kinerja karyawan sangat dipengaruhi oleh kondisi 
mental dan psikologis karyawan (motivasi dan komitmen) yang membantu meningkatkan mutu dan ketepatan dalam melakukan pekerjaan. Beberapa temuan dan pendapat ini menjadi argumentasi logis bahwa penelitian ini tidak menemukan pengaruh nyata kepuasan penilaian kinerja terhadap kinerja, meskipun hal ini masih perlu untuk dikonfirmasi melalui penelitian-penelitian selanjutnya.

Pada hubungannya dengan penerapan penilaian kinerja di PTPN $V$, pengaruh langsung nyata keadilan organisasi dalam penilaian kinerja terhadap kinerja dapat dijelaskan oleh beberapa hal. Pertama, penilaian kinerja dengan sistem CBPM adalah sistem baru yang menggantikan sistem penilaian lama. Penilaian kinerja dengan sistem CBPM ini lebih obyektif karena sudah berdasarkan indikator-indikator kinerja yang terukur, sedangkan penilaian kinerja yang lama bersifat subyektif karena indikator-indikator yang digunakan tidak terukur. Perubahan sistem penilaian ini disikapi secara positif oleh karyawan PTPN $\vee$ dibuktikan oleh nilai persepsi yang tinggi terhadap keadilan organisasi pada sistem CBPM. Hal ini meningkatkan kepercayaaan karyawan terhadap perusahaan bahwa jika karyawan berkinerja baik, maka perusahaan akan memberikan nilai kinerja yang baik. Kepercayaan yang tinggi terhadap perusahaan ini yang mendorong motivasi karyawan untuk meningkatkan kinerjanya.

Kedua, frekuensi penilaian kinerja yang diterapkan di PTPN $\vee$ adalah setahun sekali. Efek kepuasan penilaian kinerja terhadap semangat kerja lebih bersifat temporer, artinya rasa puas terhadap hasil penilaian dalam memengaruhi semangat kerja karyawan berlaku beberapa waktu setelah hasil penilaian diterima. Dalam rutinitas pekerjaan dari hari ke hari, banyak masalah-masalah yang dihadapi oleh karyawan, sehingga efek kepuasan penilaian semakin lama semakin menurun. Menurut Blau (1999), kepuasan kerja mengalami penurunan dari waktu ke waktu. Hal ini mendukung argumentasi bahwa kepuasan penilaian kinerja tidak permanen. Di sisi lain, persepsi keadilan organisasi yang dirasakan tinggi oleh karyawan memiliki pengaruh lebih permanen dalam menjaga semangat kerja karyawan karena karyawan merasa perusahaan memiliki niat baik untuk berbuat adil kepada karyawannya (sesuai teori pertukaran sosial).

Ketiga, keadilan lebih universal atau berlaku umum dibandingkan dengan kepuasan. Kepuasan penilaian terutama dirasakan oleh karyawan yang mendapatkan hasil penilaian yang baik atau sesuai harapannya. Hal ini sejalan dengan Kuvaas (2006) yang menyatakan penilaian kinerja memiliki pengaruh positif terhadap perilaku dan sikap karyawan, jika karyawan mengalami reaksi penilaian positif (hasil penilaian memuaskan). Hal ini juga dibuktikan dari jawaban responden bahwa penerimaan nilai kinerja memiliki rataan lebih tinggi (4.12) dibandingkan nilai rataan indikator puas dengan nilai (3.95). Di sisi lain, keadilan 


\section{Masrukin}

\section{Musa Hubeis \\ Hari Wijayanto}

organisasi dirasakan oleh semua karyawan, baik yang memperoleh hasil penilaian baik maupun tidak. Bagi karyawan yang memperoleh nilai baik, otomatis akan puas dengan hasil penilaian dan akan lebih bersemangat untuk mencapai target kinerjanya. Sedangkan bagi karyawan yang tidak memperoleh nilai yang baik, karyawan tersebut tetap dapat menerima hasil penilaian, meskipun tidak puas, karena karyawan memahami bahwa hasil tersebut disebabkan kinerjanya tidak tercapai. Pemahaman ini akan mendorong motivasinya untuk meningkatkan kinerja di masa berikutnya.

\section{SIMPULAN}

Keadilan organisasi dalam penilaian kinerja yang diterapkan oleh manajemen PTPN $\vee$ telah memenuhi aspek-aspek keadilan organisasi yang meliputi keadilan distributif, prosedural, interpersonal dan informasional. Kepuasan penilaian kinerja telah dinilai tinggi oleh karyawan pimpinan PTPN $\vee$ yang meliputi kepuasan nilai, kepuasan penilai dan kepuasan umpan balik. Keadilan organisasi dalam penilaian kinerja berpengaruh secara nyata terhadap kepuasan penilaian kinerja dan berpengaruh nyata secara langsung terhadap kinerja. Kepuasan penilaian kinerja tidak berpengaruh nyata terhadap kinerja sehingga kepuasan penilaian kinerja tidak berperan sebagai mediator pengaruh keadilan organisasi terhadap kinerja.

Penelitian selanjutnya dapat melakukan penelitian pada setting perusahaan dan sektor yang berbeda untuk menambah generalisasi hubungan keadilan organisasi dalam penilaian kinerja terhadap kinerja karyawan, mengkombinasikan metode self performance rated dengan supervisor's performance reported (penilaian oleh atasan) untuk pengukuran peubah kinerja dan penambahan peubah motivasi intrinsik.

\section{DAFTAR PUSTAKA}

Abekah-Nkrumah, G., \& Atinga, R. A. 2013. Exploring the link between organisational justice and job satisfaction and performance in Ghanaian hospitals: Do demographic factors play a mediating role? International Journal of Workplace Health Management, 6(3), 189-204. https://doi.org/10.1108/IJWHM-04-2011-0011.

Adams, J. S. 1963. Toward an Understanding of Inequity 1, 67(5), 422-436. https://doi.org/10.1037/h0040968. 
Aguinis, H. 2014. Performance Management. Harlow: Pearson Education Limited.

Amir, M.F. 2015. Memahami Evaluasi Kinerja Karyawan. Jakarta: Mitra Education Limited.

Blau, G. J. 1999. Testing the Longitudinal Impact of Work Variables and Performance Appraisal Satisfaction on Subsequent Overall Job Satisfaction. Human Relations 4*, 52 (8), 1099-1113. https://doi.org/10.1177/001872679905200806.

Colquitt, J. A. 2001. On the dimensionality of organizational justice: A construct validation of a measure. Journal of Applied Psychology, 86(3), 386-400. https://doi.org/10.1037/00219010.86 .3 .386$.

Fakhimi, F., \& Raisy, A. 2013. Satisfaction with performance appraisal from the employees' perspective and its behavioral outcomes (case study of headquarters offices of Bank Refah). European Online Journal of Natural and Social Sciences, 22(3), 296-305. Retrieved from www.european-science.com.

Fauziah, F. A. 2015. Pengaruh Persepsi Keadilan Distributif Pada Penilaian Kinerja terhadap Kinerja karyawan yang dimediasi oleh Kepuasan Penilaian Kinerja. Journal of $\begin{array}{llll}\text { Management, } & 5(1), & \text { Retrieved } & \text { from }\end{array}$ http://jurnal.untan.ac.id/index.php/JJ/article/view/16179.

Hadi, N. U. 2016. Making Sense of Mediating Analysis: A Marketing Perspective. Review of Integrative Business and Economics ResearchOnlineCDROM, 5(2), 62-76. https://doi.org/10.1037/a0034592.

Ibeogu, P. H., \& Ozturen, A. 2015. Perception of Justice in Performance Appraisal and Effect on Satisfaction: Empirical Findings from Northern Cyprus Banks. Procedia Economics and Finance, 23 (October 2014), 964-969. https://doi.org/10.1016/\$2212-5671(15)00359-7.

labal, Zafar M., Rehan, M., Fatima, A., \& Nawab, S. 2017. The Impact of Organizational Justice on Employee Performance in Public Sector Organization of Pakistan. International Journal of Economics \& Management Sciences, 06(03). https://doi.org/10.4172/2162-6359.1000431.

Jawahar, I. M. 2007. The influence of perceptions of fairness on performance appraisal reactions. Journal of Labor Research, 28(4), 735-744. https://doi.org/10.1007/s12122-0079014-1. 


\section{Masrukin}

\section{Musa Hubeis}

\section{Hari Wijayanto}

Kaleem, M. M., Jabeen, B., \& Twana, M. J. 2013. Organizational Justice in Performance Appraisal System: Its Effects on Performance Appraisal Satisfaction and Work Performance. International Journal of Management \& Organizational Studies, 2 (2), 2837. Retrieved from http://etd.uum.edu.my/2641.

Katavich, K. M. 2013. The Important of Employee Satisfaction with Performance Appraisal $\begin{array}{llll}\text { System. } & \text { Albany. } & \text { Retrieved }\end{array}$ https://mro.massey.ac.nz/bitstream/handle/10179/4708/02_whole.pdf?sequence=1 \&isA llowed=y.

Koopmans, L., Bernaards, C. M., Hildebrandt, V. H., De Vet, H. C. W., \& Van Der Beek, A. J. 2014. Construct validity of the individual work performance questionnaire. Journal of Occupational and Environmental Medicine, 56(3), 331-337. https://doi.org/10.1097/JOM.0000000000000113.

Koopmans, L., Bernaards, C. M., Hildebrandt, V. H., Schaufeli, W. B., De Vet Henrica, C. W., \& Van Der Beek, A. J. 2011. Conceptual frameworks of individual work performance: A systematic review. Journal of Occupational and Environmental Medicine, 53(8), 856866. https://doi.org/10.1097/JOM.0b013e318226a763.

Kreitner, A. \& Kinicki, R. 2014. Perilaku Organisasi. Jakarta: Salemba Empat.

Kuvaas, B. (2006). Performance appraisal satisfaction and employee outcomes: Mediating and moderating roles of work motivation. International Journal of Human Resource Management, 17(3), 504-522. https://doi.org/10.1080/09585190500521581

Latan H \& Ghozali I. 2012. Partial Least Square: Konsep, Teknik dan Aplikasi Menggunakan Program SmartPLS 2.0 M3. Semarang: Badan Penerbit Universitas Diponegoro.

Mangkuprawira, T. 2011. Manajemen Sumber Daya Manusia Strategik. Bogor: Ghalia Indonesia.

Mashi, M. S. 2017. The Mediating role of Job Satisfaction in the Relationship between Organizational Justice and Employee Outcomes. International Journal of Public Administration, 00 (00), 1-10. https://doi.org/10.1080/01900692.2017.1388819. 
Nasurdin, A., \& Khuan, S. 2013. Organizational justice as an antecedent of job performance. Gadjah Mada International Journal ..., 9(3), 325-343. Retrieved from http://gamaijb.mmugm.ac.id/e-journal/index.php/gamaijb/article/view/116

Noe, J.R.; Hollenbeck, B.; Gerhart, P.M. \& Wright, R. A. 2010. Manajemen Sumber Daya Manusia: Mencapai Keunggulan Bersaing. Jakarta: Salemba Empat.

Palaiologos, A., Papazekos, P., \& Panayotopoulou, L. 2011. Organizational justice and employee satisfaction in performance appraisal. Journal of European Industrial Training, 35(8), 826-840. https://doi.org/10.1108/03090591111168348

Robbins, T. A., \& Judge, S. P. 2016. Perilaku Organisasi. Jakarta: Salemba Empat.

Roch, S. G., \& Shanock, L. R. 2006. Organizational justice in an exchange framework: Clarifying organizational justice distinctions. Journal of Management, 32(2), 299-322. https://doi.org/10.1177/0149206305280115

Santosa, S. 2018. Konsep Dasar dan Aplikasi SEM dengan AMOS 24. Jakarta: PT. Elex Media Komputindo.

Sekaran, U. \& Bougie, R. 2017. Metode Penelitian untuk Bisnis. Jakarta: Salemba Empat.

Sudin, S. 2011. Fairness of and Satisfaction with Performance Appraisal Process. Journal of Global Management, (April). https://doi.org/10.1055/s-0032-1333472.

Suliman, Mohyeldin Tahir A. 2007. Links between justice, satisfaction and performance in the workplace: A survey in the UAE and Arabic context. Journal of Management Development, 26(4), 294-311. https://doi.org/10.1108/02621710710740075.

Thurston, Paul W. \& MCNall, L. 2010. Justice perceptions of performance appraisal practices. Journal of Managerial Psychology, 25(3), 201-228. https://doi.org/10.1108/02683941011023712.

Warokka, A., Gallato, C., \& Moorthy, T. 2012. Organizational Justice in Performance Appraisal System and Work Performance: Evidence from an Emerging Market. The Journal of Human Resources Management Research, 2012, 1-18. https://doi.org/10.5171/2012.159467. 
Masrukin

Musa Hubeis

Hari Wijayanto

Wibowo. 2013. Perilaku dalam Organisasi. Jakarta: Rajawali Press.

Zhao, X., Lynch, J. G., \& Chen, Q. 2010. Reconsidering Baron and Kenny: Myths and Truths about Mediation Analysis. Journal of Consumer Research, 37(2), 197-206. https://doi.org/10.1086/651257. 